\section{Antimycobacterial activity of the fractions and compounds from Scutia buxifolia}

\author{
Aline A. Boligon, ${ }^{* 1}$ Vanessa Agertt, ${ }^{2}$ Vanessa Janovik, ${ }^{1}$ Ritiel C. \\ Cruz, ${ }^{1}$ Marli M. A. Campos, ${ }^{2}$ Dominique Guillaume, ${ }^{3}$ Margareth \\ L. Athayde, ${ }^{1}$ Adair R. S. dos Santos ${ }^{4}$
}

\author{
${ }^{1}$ Laboratório de Pesquisa Fitoquímica, Departamento de Farmácia Industrial, \\ Universidade Federal de Santa Maria, Brazil, \\ ${ }^{2}$ Laboratório de Pesquisa Micobacteriológica, Departamento de Análises Clínicas \\ e Toxicológicas, Universidade Federal de Santa Maria, Brazil, \\ ${ }^{3}$ Medicinal Chemistry Department, Université Reims-Champagne Ardenne, \\ France, \\ ${ }^{4}$ Departamento de Ciências Fisiológicas, Centro de Ciências Biológicas, \\ Universidade Federal de Santa Catarina, Brazil.
}

Revista Brasileira de Farmacognosia Brazilian Journal of Pharmacognosy 22(1): 45-52, Jan./Feb. 2012

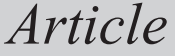

Received 3 Feb 2011 Accepted 27 Apr 2011 Available online 7 Oct 2011

Keywords: antimycobacterial flavonoids HPLC phenolics Scutia buxifolia

ISSN 0102-695X http://dx.doi.org/10.1590/S0102695X2011005000182

\section{Introduction}

More and more people in developing countries utilize traditional medicine for their major primary health care needs (Houghton, 1995). The use of medicinal plants for the treatment of several diseases, including fungal and bacterial infections is typical in Brazil (Carvalho et al., 2002; Pereira et al., 2007; Schubert et al., 2007) and worldwide many research groups screen plant extracts to detect secondary metabolites with antimicrobial properties in an attempt to find new antimycobacterial or antifungal compounds (Cos et al., 2006; Soberón et al., 2007; Rangasamy et al., 2007). Plant-derived compounds are a potential source for investigation of alternative lead chemical structures for drug development (McGaw et al., 2008). Essential oils, alkaloids, terpenoids, phenolics acids, peptides, flavonoids, tannins and coumarins represent the principal groups of compounds extracted from plants with antimycobacterial properties described in the literature (Esquenazi et al., 2002; Morel et al.,
2005; Duarte et al., 2007; Peng et al., 2008; Lechner et al., 2008; McGaw et al., 2008; Honda et al., 2010).

The great increase of the resistance of pathogenic microorganisms to multiples drugs occurs owing to the indiscriminate use of antimicrobial, hence there is worry for a search of the new alternative therapeutics (Novais et al., 2003; Antunes et al., 2006; Oliveira et al., 2006; Oliveira et al., 2007; Edgar et al., 2009). Medicinal plants are of great interest scientific, because there is the possibility of use like to phytopharmacos, or big chance to obtain up molecules prototypes due its diversity of constituents (Grayer \& Harborner, 1994; Nascimento et al., 2000; Mallavarapu, 2001; Lima et al., 2006). Over 350 natural products, mainly plant species, which have been used in traditional medicine, have been assessed for their antimycobacterial activities (Newton et al., 2000; Copp, 2003). A number have been shown to demonstrate significant in vitro antimycobacterial activities and active plant-derived compounds belonging to various chemical classes have been isolated. These findings have therefore stimulated further research towards the isolation of new 
antimycobacterial agents from natural products (Newton et al., 2002).

Mycobacterial infections including Mycobacterium tuberculosis as well as fast-growing strains are increasing globally; the tubeculosis caused 8 million new cases and 1.8 million fatalities per annum worldwide (Dye, 2006). The mycobacterial are bacilli aerobic no mobile alcohol acid resistant, its surface is rich in mycolic acid. The M. smegmatis is a mycobacterium associate to infections as lung disease, despite not being the causative agent of tuberculosis; $M$. smegmatis has been used successfully in many studies due to the characteristic of rapid growth and ease of handling (Pauli et al., 2005). Mycobacterium avium is usually opportunistic pathogen, non-pathogenic in healthy individuals, infections caused by $M$. avium is prevalent in patients with AIDS, affecting as many as $40 \%$ of patients with advanced disease, which is resistant to most existing antimicrobials (Ramos et al., 2000; Collins \& Franzblau, 1997). The additional prevalence of multidrug-resistant strains and extensively drugresistant tuberculosis (De Rossi et al., 2006) stimulates an urgent need for the development of new drugs for the treatment of mycobacterial infections.

Scutia buxifolia Reissek belongs to the Rhamnaceae family and is popularly known as "coronilha". It is native tree from South America, with a dispersion area that comprises Rio Grande do Sul State in Brazil, and the countries Argentina and Uruguay. The root bark infusion is popularly used as cardiotonic, antihypertensive and diuretic (Wasicky et al., 1964). Antimicrobial activities of some cyclopeptide alkaloids isolated from the root bark of $S$. buxifolia were reported by Morel et al. (2005), using the bioautography method. The objectives of the present work were obtain the profile by HPLC of fractions obtained from the leaves of $S$. buxifolia and evaluate the antimycobacterial activity of the same fractions, using the broth microdilution method (NCCLS, 2003) which is a very sensitive method to screen plant extracts to prospect antimicrobial.

\section{Material and Methods}

\section{Chemicals apparatus and general procedures}

Methanol and acetonitrile were of HPLC grade and acquired from Sigma Chemical Co. (St. Louis, MO, USA). Solvents for the extractions, dichloromethane, ethyl acetate, ethanol, methanol, n-butanol and dimethylsulfoxide (DMSO) were purchased from Merck (Darmstadt, Germany). Quercetin, quercitrin, gallic acid and caffeic acid, Alamar Blue and Tetrazolium bromide [3-(4, 5-dimethylthiazol-2-yl)-2,5-diphenyltetrazolium bromode] (MTT) were acquired from Sigma Chemical Co. (St. Louis, MO, USA). Lowenstein-Jensen medium, Middlebrook 7H9 broth, OADC (oleic acidalbumin-dextrose-catalase) were purchased from Difco Laboratories (Detroit, Mich). Silica Gel Merck 70-230 mesh was used for column chromatography and silica gel Merck GF254nm was used for thin layer chromatography. High performance liquid chromatography (HPLC-DAD) was performed with the HPLC system (Shimadzu, Kyoto, Japan), Prominence Auto-Sampler (SIL-20A), equipped with Shimadzu LC-20 AT reciprocating pumps connected to the degasser DGU 20A5 with integrator CBM 20A, UV-VIS detector DAD SPD-M20A and Software LC solution 1.22 SP1.

\section{Plant collection}

Leaves of Scutia buxifolia Reissek, Rhamnaceae, were collected on October of 2007 in the first district of the council of Dom Pedrito, in the Rio Grande do Sul State, Brazil (coordinates 30 59'09' S and $54^{\circ} 27^{\prime} 44^{\prime \prime} \mathrm{W}$ ). Voucher specimen was archived in the herbarium of Department of Biology at Federal University of Santa Maria, register number SMBD 10919.

\section{Extraction}

The leaves $(372.34 \mathrm{~g})$ of the plant were dried at room temperature, powdered in a knife mill $(0.86$ $\mu \mathrm{m})$ and macerated with $2 \mathrm{~L}$ of ethanol $70 \%$ during a week. After filtration, the extracts were evaporated under reduced pressure to remove the ethanol. The remaining aqueous extract was partitioned with dichloromethane, ethyl acetate and $n$-butanol ( $3 \times 100 \mathrm{~mL}$ for each solvent). At the end of all extractions procedures, furnished three extracts with different polarities and properties. These extracts were dried under reduced pressure using a rotatory evaporator at $40{ }^{\circ} \mathrm{C}$.

\section{Fractionation}

The ethyl acetate extract of the leaves $(4 \mathrm{~g})$ was submitted to a column chromatography on silica gel $60(225 \mathrm{~g})$, eluted with $\mathrm{CH}_{2} \mathrm{Cl}_{2} / \mathrm{EtOH}(1: 0-0: 1)$. Ninety-six fractions $( \pm 50 \mathrm{~mL}$ each fraction) were collected and their composition monitored by thinlayer chromatography (TLC), so grouped on the basis of similarity chromatographic profile to obtain seven fractions (I-VII). Fraction I (fractions 1-8, $15 \mathrm{mg}$ ), fraction II (fractions 9-51, $24 \mathrm{mg}$ ), Fraction III (fractions 52-68, $92 \mathrm{mg}$ ), Fraction IV (fractions 69-80, $67 \mathrm{mg}$ ), Fraction V (fractions 81-82, $51 \mathrm{mg}$ ), Fraction VI (fractions 83-89, 17 $\mathrm{mg}$ ), VII (fractions 90-96, $18 \mathrm{mg}$ ). Detailed isolation of quercitrin and quercetin is published elsewhere (Boligon et al., 2009a). 


\section{Quantification of phenolics compounds by HPLC}

Reverse phase chromatographic analyses were carried out in isocratic conditions using C-18 column $(4.6 \mathrm{~mm} \times 250 \mathrm{~mm})$ packed with $5 \mu \mathrm{m}$ diameter particles, the mobile phase was methanol-acetonitrilewater $(40: 15: 45, \mathrm{v} / \mathrm{v} / \mathrm{v})$ containing $1.0 \%$ acetic acid. The mobile phase was filtered through a $0.45 \mu \mathrm{m}$ membrane filter and then degassed by an ultrasonic bath prior to use. Stock solution of quercetin, gallic acid and caffeic acid standard reference was prepared in the HPLC mobile phase at a concentration range of 0.018 to $0.280 \mathrm{mg} / \mathrm{mL}$ (Artani et al., 2006). The fractions I, II, III, IV, V, VI and VII from the leaves were also dissolved in the mobile phase. Quantification was carried out by the integration of the peak using external standard method. The flow rate was $1.0 \mathrm{~mL} / \mathrm{min}$, injection volume was $20 \mu \mathrm{L}$ and detection were done at $257 \mathrm{~nm}$ for gallic acid, $325 \mathrm{~nm}$ for caffeic acid and $365 \mathrm{~nm}$ for quercetin and quercitrin. The chromatographic peaks were confirmed by comparing their retention time and DAD-UV spectra with those of the reference standards and by spiking the isolated compounds in the plant sample. The calibration curve for gallic acid was: $\mathrm{Y}=53985 \mathrm{x}-1020.6(\mathrm{r}=0.998)$, the curve of caffeic acid was: $\mathrm{Y}=15972 \mathrm{x}-7081.4(\mathrm{r}=0.995)$, and the curve of quercetin was: $Y=15083 \mathrm{x}-4627.1(\mathrm{r}=0.989)$. All chromatographic operations were performed at room temperature and in triplicate.

\section{Antimicrobial assay on Mycobacterium}

Antimycobacterial activity was tested against Mycobacterium smegmatis $\mathrm{mc}^{2} 155$ (ATCC 700084), M. tuberculosis H37Rv (ATCC 25618) and M. avium LR541CDC. The stored mycobacterias were seeded onto Löwenstein-Jensen medium and incubated during 3-5 days. From this culture a portion was removed and placed into Middlebrook $7 \mathrm{H} 9$ broth, supplemented with $10 \%$ OADC and $0.2 \%$ glycerol (MD7H9) and then homogenized in ultrasonic bath for one minute. The concentration of bacteria in this medium was determined by optical density on spectrophotometer ( 0.08 to 0.1 of absorbance at $625 \mathrm{~nm}$ ) of $0.5 \mathrm{McF}$ arland scale and then diluted with MD7H9 up to $10^{5} \mathrm{CFU} /$ $\mathrm{mL}$ for $M$. smegmatis, to reach the inoculum. The $M$. tuberculosis and M. avium were used at a concentration of 0.5 McFarland (not diluted) because they are slowgrowing. Plant extracts, fractions and isolated were dissolved in DMSO, at a concentration of $50.00 \mathrm{mg} /$ $\mathrm{mL}$ and then diluted in MD7H9 until the desired concentrations, beginning the series with $2500.00 \mu \mathrm{g} /$ $\mathrm{mL}$.

The activity test were performed using the broth microdilution method (NCCLS, 2003), which presented as a result the minimum inhibitory concentrations (MIC) of each compound. $100 \mu \mathrm{L}$ of mycobacterial culture were placed in each well of a microtitre plate, as well as the extracts and fractions at correspondent concentrations. Analysis were carried out in triplicate, controls were made to the medium and to the mycobacterium, and one blank for each concentration of samples. The plates were incubated during $48 \mathrm{~h}$ at $37{ }^{\circ} \mathrm{C}$. The Alamar Blue (Franzblau et al., 1998) or MTT (Sankar et al., 2008) dye were used to check the growth of microorganisms. The Alamar Blue was diluted in a ratio of $1 / 10$ with Tween 80 , diluted to $1 / 9$ with sterile water, supplemented with $0.025 \mathrm{~mL}$ in each well, considering the MIC into the pit where there was no change in color from purple to pink. MTT solution at $0.5 \mathrm{mg} / \mathrm{mL}$ were prepared by the dilution with absolute ethanol up to $1 \mathrm{mg} / \mathrm{mL}$, and then by dilution half to half with a solution of $10 \%$ Tween 80 . $25 \mu \mathrm{L}$ of the final solution were added to each plate well, and the well where the drug prevented the color change from yellow to purple was considered the MIC.

\section{Results and Discussion}

The yields of dichloromethane, ethyl acetate and $n$-butanol-soluble fractions obtained after the partition of the remaining aqueous extract are given in Table 1. The highest yield was obtained with ethyl acetate solvent.

Table 1. Yielding expressed in grams and in percentage for all extracts.

\begin{tabular}{lc}
\hline Extracts of the leaves & Yielding of the extracts \\
\hline Dichloromethane & $1.134 \mathrm{~g}(0.30 \%)$ \\
Ethyl acetate & $20.183 \mathrm{~g}(5.41 \%)$ \\
Butanolic & $13.490 \mathrm{~g}(3.62 \%)$ \\
\hline
\end{tabular}

Extracts from the leaves of $S$. buxifolia were tested against $M$. smegmatis to determine the promissory extract to continue the experiment. The dichloromethane and ethyl acetate extracts of the leaves showed the good MIC $(312.50 \mu \mathrm{g} / \mathrm{mL})$, due to the higher yield, the ethyl acetate extract was prioritized. The results for the dichloromethane extract is probably related to the presence of triterpenes and sterol reported for this extract (Boligon et al., 2010) which have antimycobacterial activity demonstrated (Cantrell et al., 2001). However, the values found for the ethyl acetate extract are related to the presence of flavonoids contents (Boligon et al., 2009a; Boligon et al., 2009b).

The fractions I, II, III, IV, V, VI and VII of $S$. buxifolia leaves were analyzed by HPLC. The result indicates that the $S$. buxifolia contains several compounds including gallic acid with retention time $\left(\mathrm{t}_{\mathrm{R}}\right)$ of $3.3 \mathrm{~min}$ (peak 1), caffeic acid with $\mathrm{t}_{\mathrm{R}}=5.0 \mathrm{~min}$ (peak 2), quercitrin with $t_{R}=6.4$ min (peak 3 ) and quercetin with $t_{R}=12.1 \mathrm{~min}$ (peak 4), (Figure 1). 

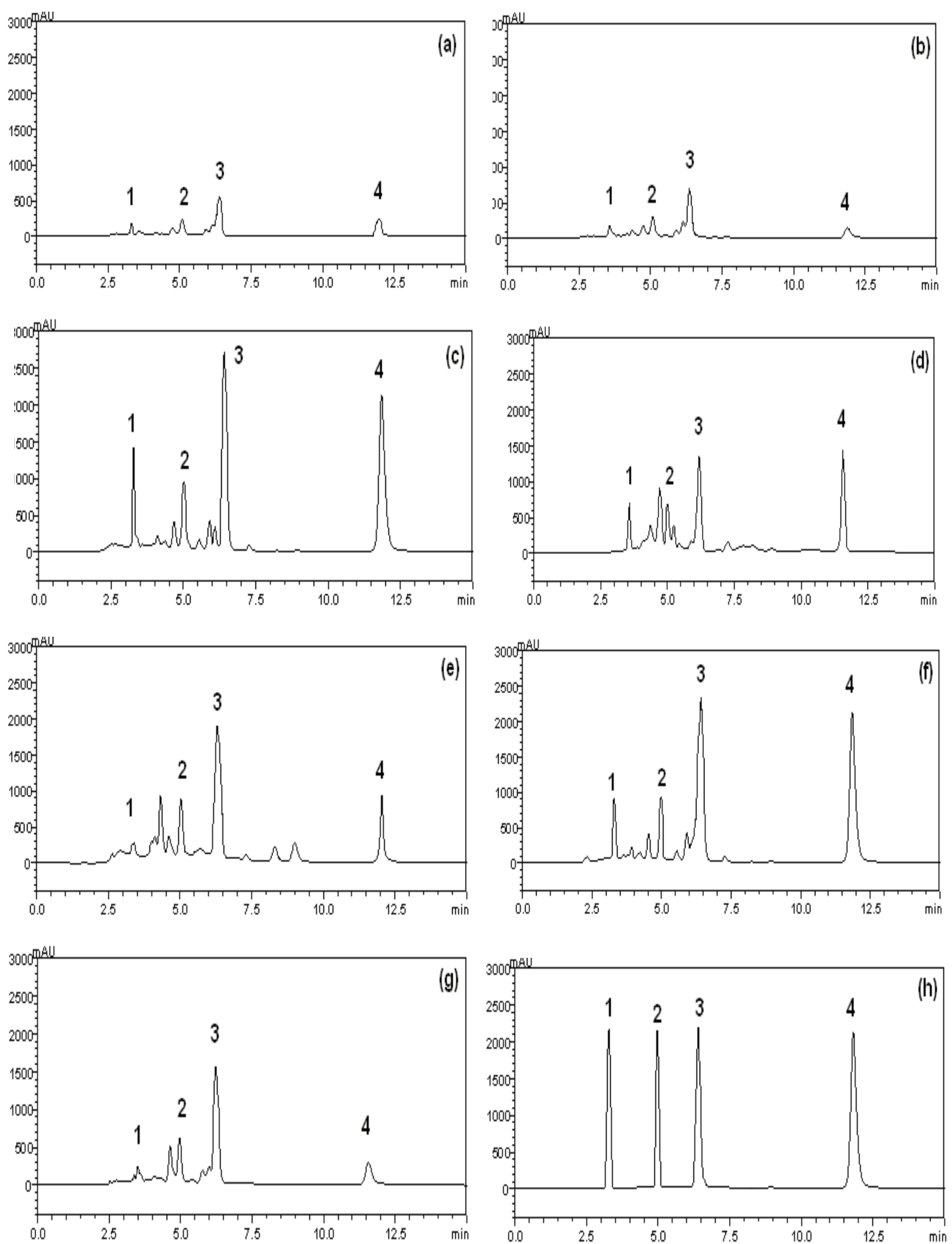

Figure 1. High performance liquid chromatography phenolic profile of ethyl acetate fraction from the leaves: fraction I (a), fraction II (b), fraction III (c), fraction IV (d), fraction V (e), fraction VI (f), fraction VII (g) and standards (h). Gallic acid (1), caffeic acid (2), quercitrin (3) and quercetin (4). Chromatographic conditions described in the experimental section. 
The HPLC profile of seven active fractions was also acquired, as well the quantification of quercetin, quercitrin, gallic and caffeic acids by HPLC-DAD based in the reference standards (Table 2). Quercetin $(27.1 \pm 0.03$ $\mathrm{mg} / \mathrm{g})$ and quercitrin $(183.2 \pm 0.24 \mathrm{mg} / \mathrm{g})$ were also quantified by Boligon et al. (2009b) in the ethyl acetate extract of $S$. buxifolia, using the same chromatographic conditions.

In vitro screening techniques for detecting antimycobacterial in plant extracts and isolated compounds are varied; the Broth dilution techniques offer benefits such as ease of operation, no expensive equipment needs and, in a microplate format, low sample volumes. Many researchers have made use of the 96well microplate format to screen test substances for antimycobacterial activity against $M$. tuberculosis, for example the Microplate Alamar Blue Assay or MABA. Microplate assay that use Alamar Blue or tetrazoliumtype compounds have the potential of becoming the methods of choice for drug susceptibility testing of $M$. tuberculosis. Similar considerations would apply for any of the slow-growing pathogenic mycobacteria including M. avium and M. bovis (McGaw et al., 2008; Collins \& Franzblau, 1997).

Several researchers have utilized nonpathogenic, fast-growing Mycobacterium species in rapid and easy screens for antimycobacterial activity in plant extract and pure plant-derived compounds (Brown et al., 2007; Kuete et al., 2008). In one study realized by McGaw et al. (2008) was concluded that M. smegmatis was better predictor of activity against pathogenic $M$. tuberculosis. However, more research is needed to validate the use of non-pathogenic species such as $M$. smegmatis as models for detecting activity of plantderived extracts against pathogenic M. tuberculosis.

The antimycobacterial activity against $M$. smegmatis, M. tuberculosis and M. avium is a new addition to the activities reported for this plant, the results of the antimycobacterial assays have been reported in Table 3. The all tested samples of the leaves

Table 2. Fractions composition of Scutia buxifolia leaves.

\begin{tabular}{lccc}
\hline \multicolumn{1}{c}{$\begin{array}{c}\text { Fractions } \\
\text { of the leaves }\end{array}$} & $\begin{array}{c}\text { Gallic acid } \\
(\mathrm{mg} / \mathrm{g} \text { of dry fraction*) }\end{array}$ & $\begin{array}{c}\text { Caffeic acid } \\
(\mathrm{mg} / \mathrm{g} \text { of dry fraction*) }\end{array}$ & $\begin{array}{c}\text { Quercitrin** } \\
(\mathrm{mg} / \mathrm{g} \text { of dry fraction*) }\end{array}$ \\
\hline Fraction I & $21.03 \pm 0.07$ & $29.12 \pm 0.09$ & $\begin{array}{c}\text { Quercetin } \\
(\mathrm{mg} / \mathrm{g} \text { of dry fraction*) }\end{array}$ \\
Fraction II & $18.55 \pm 0.15$ & $31.05 \pm 0.06$ & $51.64 \pm 0.34$ \\
Fraction III & $132.36 \pm 0.18$ & $109.29 \pm 0.37$ & $418.28 \pm 0.33$ \\
Fraction IV & $79.13 \pm 0.19$ & $67.22 \pm 0.11$ & $191.9 \pm 0.67$ \\
Fraction V & $31.04 \pm 0.24$ & $97.08 \pm 0.05$ & $248.8 \pm 0.16$ \\
Fraction VI & $99.11 \pm 0.07$ & $103.92 \pm 0.23$ & $318.17 \pm 0.02$ \\
Fraction VII & $36.22 \pm 0.41$ & $74.06 \pm 0.09$ & $226.02 \pm 0.09 .09$ \\
\hline
\end{tabular}

*Results are expressed as mean $\pm \mathrm{SE}$ of three determinations; **Quantified as quercetin.

Table 3. Minimal inhibition concentration $(\mu \mathrm{g} / \mathrm{mL})$ of fractions and isolated of the leaves of Scutia buxifolia against M. smegmatis, M. tuberculosis and M. avium.

\begin{tabular}{lccc}
\hline \multirow{2}{*}{ Extract and fractions } & M. smegmatis & M. tuberculosis & M. avium \\
\cline { 2 - 4 } Crude extract & $>2500.00$ & Leaves & ND \\
Dichloromethane & 312.50 & ND & ND \\
Ethyl acetate & 312.50 & ND & ND \\
$n$-Butanolic & $>2500.00$ & ND & ND \\
Fraction I & 1250.00 & 312.50 & 1250.00 \\
Fraction II & 1250.00 & 625.00 & 625.00 \\
Fraction III & 78.12 & 156.25 & 312.50 \\
Fraction IV & 312.50 & 312.50 & 625.00 \\
Fraction V & 312.50 & 312.50 & 625.00 \\
Fraction VI & 156.25 & 156.25 & 312.50 \\
Fraction VII & 312.50 & 625.00 & 625.00 \\
Quercetin & 625.00 & 312.50 & 2500.00 \\
Quercitrin & 312.50 & 625.00 & 1250.00 \\
Caffeic acid & $>2500.00$ & ND & ND \\
Gallic acid & $>2500.00$ & ND & ND \\
\hline
\end{tabular}

ND: Not Determined. 
(except crude extract and $n$-butanolic fraction) were found to be active on $M$. smegmatis and the MIC ranged from 78.12 to $1250.00 \mu \mathrm{g} / \mathrm{mL}$. The lowest MIC of the $78.12 \mu \mathrm{g} / \mathrm{mL}$ against $M$. smegmatis was noted for the fraction III, this fraction together with the fraction VI showed the best activity against $M$. tuberculosis and $M$. avium exhibiting an MIC of $156.25 \mu \mathrm{g} / \mathrm{mL}$ and 312.50 $\mu \mathrm{g} / \mathrm{mL}$, respectively. Tosun et al. (2004) considered inactive the plant extracts that could not prevent growth of mycobacterium up to concentration of $200.00 \mu \mathrm{g} /$ $\mathrm{mL}$. In this sense, we considered a promising result the MIC of 78.12 and $156.25 \mu \mathrm{g} / \mathrm{mL}$ found in fraction III and VI.

The fraction III (Figure 1c) and VI (Figure 1f) have the highest amount of flavonoids and phenolics acids when compared to other fractions tested (Table 2). This suggests that the interaction between compounds presents from these fractions might be important for the activity against $M$. tuberculosis, M. smegmatis and M. avium.

Quercetin and quercitrin were predominantly present in the fraction III and VI, flavonoids are well known for their antimicrobial potencies (Cowan, 1999). Several studies have demonstrated activity of flavonoids against mycobacterium, such as luteolin (MIC 78.12 $\mu \mathrm{g} / \mathrm{mL}$ for $M$. tuberculosis and $M$. smegmatis), genistein (MIC $19.53 \mu \mathrm{g} / \mathrm{mL}$ for M. tuberculosis and $M$. smegmatis) and alpinum isoflavone (MIC $19.53 \mu \mathrm{g} / \mathrm{mL}$ for M. smegmatis) isolated from Ficus chlamydocarpa, licoisoflavanone isolated from the medicinal plant Glycyrrhiza glabra and quercetin 3'7-di-O-methyl-3 sulphate and kaempferol 7-O-methyl 3 sulphate isolated of Argyreia speciosa presented MIC of 25.00 $\mu \mathrm{g} / \mathrm{mL}$ against $M$. tuberculosis and 4'-hydroxy-5,7,3'trimethoxyflavan-3-ol isolated from Cinnamomum kotoense (MIC $150.60 \mu \mathrm{g} / \mathrm{mL}$ ) (Copp, 2003; Chen et al., 2005; Kuete et al., 2008).

In a recent study by Askun et al. (2009) reports the antimycobacterial activity (M. tuberculosis) of the methanolic extracts of Thymbra spicata var. spicata and Origanum minutiflorum, which presented MIC of 196.00 and $392.00 \mu \mathrm{g} / \mathrm{mL}$ respectively, among the components of these extracts was identified flavonoid that screened in this study, like quercetin. Brown et al (2007) investigated the antimycobacterial activity of the flavonoid butein (MIC $43.00 \mu \mathrm{g} / \mathrm{mL}$ ) and isoliquiritigenin (MIC $50.00 \mu \mathrm{g} / \mathrm{mL}$ ) and concluded that its effects may be related to their inhibitory effect on fatty acid and mycolic acid biosynthesis.

Lechner et al. (2008) tested flavonoids with different substitution patterns, using different mycobacterial strains, M. smegmatis (ATCC 14468), $M$. smegmatis $\mathrm{mc}^{2} 155$ (ATCC 700084) and M. smegmatis $\mathrm{mc}^{2}$ 2700. The results using the same strain M. smegmatis $\mathrm{mc}^{2}$ 155 (ATCC 700084) used in our study were epicatechin $(\mathrm{MIC}>128.00 \mu \mathrm{g} / \mathrm{mL})$, isorhamnetin (MIC $>256.00$ $\mu \mathrm{g} / \mathrm{mL}$ ), kaempferol (MIC>256.00 $\mu \mathrm{g} / \mathrm{mL})$, luteolin $(\mathrm{MIC}=128-256.00 \mu \mathrm{g} / \mathrm{mL}$ ), myricetin (MIC $32.00 \mu \mathrm{g} /$ $\mathrm{mL})$, quercetin $(\mathrm{MIC}>256.00 \mu \mathrm{g} / \mathrm{mL})$, rutin and taxifolin (MIC $>128.00 \mu \mathrm{g} / \mathrm{mL}$ ). Generally, simple flavonols and its glycosides like quercetin, quercitrin and rutin possess a moderated antimycobacterial activity against both, fast (M. smegmatis) and slow (M. tuberculosis) growing mycobacteria. Flavones and flavanones have been exhibiting better results, like those obtained by Kuete et al. (2008) and Lechner et al. (2008), where genistein, alpinum isoflavone, laburnetin presented low MIC against $M$. tuberculosis.

Flavonoids can inhibit enzymes involved in the fatty acid and mycolic acid biosynthesis in vivo. Mycolic acids are one of the most distinctive features of the mycobacteria cell wall, essential for its survival. Considering the structure of flavonoids, the ketone group emulates the carbonyl group of a fatty acid substrate, and they all possess a 2,3 double bond consistent with a product mimic. Furthermore, the most potent inhibitors of FAS-II (fatty acid synthase II) do not support the oxygen containing cycle possessed by quercetin. The activity of these compounds against Mycobacterium certainly represents an important potential target for future drug development studies (Brown et al., 2007).

The data obtained from this study demonstrated that flavonoids are among the chemical classes responsible for the antimycobacterial activity of the plant reported here. Several authors have documented the antibacterial and antifungal potency of flavonoids (Cowan, 1999; Koysomboon et at., 2006; Kuete et al., 2007a; Kuete et al., 2007b; Kuete et al., 2008). This activity may be due to its ability to complex with bacterial cell wall (Cowan, 1999) and thus inhibiting microbial growth. Though the plant mixture is used traditionally, the results this study showed that the fractions from $S$. buxifolia leaves could be used alone with good efficiency.

Gallic and caffeic acids standards showed no antimycobacterial (both MIC over $2500.00 \mu \mathrm{g} / \mathrm{mL}$ against $M$. smegmatis). Rauha et al. (2000) demonstrated that caffeic acid does not even have an inhibitory effect against Gram-positive and negative bacteria. This way, do not contribute to the promising activities found for the fractions of S. buxifolia.

To the best of our knowledge the antimycobacterial activity from $S$. buxifolia and its fractions is being reported for the first time. Fraction III and VI of plant were active against $M$. tuberculosis and M. smegmatis. The present study provides an important basis for the use of fraction from $S$. buxifolia for the treatment of infections associated with the studied microorganisms. The fractions could be useful for the development of new antimicrobial drugs. However, pharmacological and toxicity studies are currently going on in our laboratory and will be necessary to confirm this hypothesis. 


\section{Acknowledgements}

The authors thank the financial support of CAPES/Brazil. The authors would like to thank V. Batista (Fazenda Tarumã, Dom Pedrito, Brazil) for plant collection and RB Zacchia (Botanical Department of Federal University of Santa Maria) for providing the identification of S. buxifolia.

\section{References}

Antunes RMP, Lima EO, Pereira MSV, Câmara CA, Arruda TA, Catão RMR, Barbosa TP, Nunes XP, Dias CS, Silva, TMS 2006. Atividade antimicrobiana "in vitro" e determinação da concentração inibitória mínina (CIM) de fitoconstituintes e produtos sintéticos sobre bactérias e fungos leveduriformes. Rev Bras Farmacogn 16: $517-$ 524.

Artani N, Marifa Y, Hanafi M 2006. Isolation and identification of active antioxidant compound from Star fruit (Averrhoa carambola) Mistletoe (Dendrophthoe pentandra L.) Miq. ethanol extract. J Appl Sci 68: 1659-1663.

Askun T, Tumen G, Satil F, Ates M 2009. In vitro activity of methanol extracts of plants used as spices against Mycobacterium tuberculosis and other bacteria. Food Chem 116: 289-294.

Boligon AA, Feltrin A, Machado MM, Janovik V, Athayde ML 2009a. HPLC analysis and phytoconstituents isolated from ethyl acetate fraction of Scutia buxifolia Reiss. leaves. Lat Am J Pharm 28: 121-124.

Boligon AA, Janovik V, Feltrin AC, Machado MM, Frohlich JK, Athayde ML 2010. Fitoconstituintes isolados da fração em diclorometano das cascas do tronco de Scutia buxifolia Reissek. Lat Am J Pharm 29: 450-453.

Boligon AA, Pereira RP, Feltrin AC, Machado MM, Janovik V, Rocha JBT, Athayde ML 2009b. Antioxidant activities of flavonol derivatives from the leaves and stem bark of Scutia buxifolia Reiss. Biores Technol 100: 6592-6598.

Brown AK, Papaemmanouil A, Bhowruth V, Bhatt A, Dover LG, Besra GS 2007. Flavonoid inhibitors as novel antimycobacterial agents targeting Rv0636, a putative dehydratase enzyme involved in Mycobacterium tuberculosis fatty acid synthase II. Microbiol 153: 3314-3322.

Cantrell CL, Franzblau SG, Fischer NH 2001. Antimycobacterial plant terpenoids. Planta Med 67: 685-694.

Carvalho AAT, Sampaio MCC, Sampaio FC, Melo AFM, Sena KXFR, Chiappeta AA, Higino JH 2002. Atividade antimicrobiana "in vitro" de extratos hidroalcoólicos de Psidium guajava L. sobre bactérias Gram-negativas. Lat Am J Pharm 21: 255-258.

Chen FC, Peng CF, Tsai IL, Chen IS 2005. Antitubercular constituents from the stem wood of Cinnamomum kotoense. J Nat Prod 68: 1318-1323.

Collins LA, Franzblau SG 1997. Microplate alamar blue assay versus BACTEC 460 system for high-throughput screening of compounds against Mycobacterium tuberculosis and Mycobacterium avium. Antimicrob Agents and Chemother 41: 1004-1009.

Copp BR 2003. Antimycobacterial natural products. Nat Prod Rep 20: 535-557.

Cos P, Vlietinck AJ, Berghe DV, Maes L 2006. Anti-infective potential of natural products: how to develop a stronger in vitro 'proof-of-concept'. J Ethnopharmacol 106: 290-302.

Cowan MM 1999. Plant products as antimicrobial agents. Clin Microbiol Rev 12: 564-582.

De Rossi E, Ainsa JA, Riccardi G 2006. Role of mycobacterial efflux transporters in drug resistance: an unresolved question. Microbiol Rev 30: 36-52.

Duarte MCT, Leme EE, Delarmelina C, Soares AA, Figuera GM, Sartoratto A 2007. Activity of essential oils from Brazilian medicinal plants on Escherichia coli. J Ethnopharmacol 111: 197-201.

Dye C 2006. Global epidemiology of tuberculosis. Lancet 367 : 938-940.

Edgar T, Boyd SD, Palame MJ 2009. Sustainability for behaviour change in the fight against antibiotic resistance: a social marketing framework. J Antimicrobial Chem 63: 230237.

Esquenazi D, Wigg MD, Miranda MMFS, Rodrigues HM, Tostes JBF, Rozental S, Silva AJR, Alviano CS 2002. Antimicrobial and antiviral activities of polyphenolics from Cocos nucifera Linn. (Palmae) husk fiber extract. Res Microbiol 153: 647-652.

Franzblau SG, Witzing RS, McLaughlin JC, Torres P, Madico G, Hernandez A, Degnan MT, Cook MB, Quenzer VK, Ferguson RM, Gilman RH 1998. Rapid, low-technology MIC determination with clinical Mycobacterium tuberculosis isolates by using the Microplate Alamar Blue Assay. J Clincal Microbiol 36: 362-366.

Grayer MJ, Harborne JB 1994. A survey of antifungal compounds from higher plants, 1982-1993. Phytochemistry 37: 19-42.

Honda NK, Pavan FR, Coelho RG, de Andrade Leite SR, Lopes TIB, Misutsu MY, Beatriz A, Brum RL, Leite CQF 2010. Antimycobacterial activity of lichen substances. Phytomedicine 17: 328-332.

Houghton PJ 1995. The role of plants in traditinal medicine and current therapy. J Altern Complement Med 1: 131-143.

Koysomboon S, Altena IV, Kato S, Chantrapromma K 2006. Antimycobacterial flavonoids from Derris indica. Phytochemistry 67: 1034-1040.

Kuete V, Eyong KO, Folefoc GN, Beng VP, Hussain H, Krohn $\mathrm{K}$, Nkengfack AE 2007b. Antimicrobial activity of the methanolic extract and of chemical constituents isolated from Newbouldia laevis. Pharmazie 62: 552-556.

Kuete V, Konga Simo I, Ngameni B, Bigoga DJ, Watchueng J, Nzesse Kapguep R, Etoa FX, Ngadjui TB, Penlap BV 2007a. Antimicrobial activity of the methanolic extract, 
fractions and four flavonoids from the twigs of Dorstenia angusticornis Engl. (Moraceae). J Ethnopharmacol 112: 271-277.

Kuete V, Ngameni B, Fotso Simo CC, Kengap Tankeu R, Tchaleu Ngadjui B, Meyer JJM, Lall N, Kuiate JR 2008. Antimicrobial activity of the crude extracts and compounds from Ficus chlamydocarpa and Ficus cordata (Moraceae). J Ethnopharmacol 120: 17-24.

Lechner D, Gibbons S, Bucar F 2008. Modulation of isoniazid susceptibility by flavonoids in Mycobacterium. Phytochem Lett 1: 71-75.

Lima MRF, Ximenes CPA, Luna JS, Santana AEG 2006. The antibiotic activity of some Brazilian medicinal plants. Rev Bras Farmacogn 16: 300-306.

Mallavarapu GO 2001. Contribution of medicinal plants to modern medicine. J Med Plants Modern Medicine 22: 572-578.

McGaw LJ, Lall N, Hlokwe TM, Michel AL, Meyer JJM, Eloff JN 2008. Purified compounds and extract from Euclea species with antimycobacterial activity against Mycobacterium bovis and fast-growing mycobacteria. Biol Pharm Bull 31: 1429-1433.

Morel AF, Maldaner G, Ilha V, Missau F, Silva FU, Dalcol I 2005. Cyclopeptide alkaloids from Scutia buxifolia Reiss and their antimicrobial activity. Phytochemistry 66: 2571-2576.

Nascimento GG, Locatelli J, Freitas PC 2000. Antibacterial activity of plants extracts and phytochemical on antibiotic-resistant bacteria. Braz J Microbiol 31: 247 256.

NCCLS 2003. Methods for dilution antimicrobial susceptibility tests for bacteria that grow aerobically: approved standard - Sixth Edition. NCCLS document M7-A6 (ISBN 1-56238-486-4). NCCLS, 940 West Valley Road, Suite 1400, Wayne, Pennsylvania 19087-1898 USA.

Newton SM, Lau C, Gurcha SS, Besra GS, Wright CW 2002. The evaluation of forty-three plant species for in vitro antimycobacterial activities; isolation of active constituents from Psoralea corylifolia and Sanguinaria canadensi. J Ethnopharmacol 79: 57-67.

Newton SM, Lau C, Wright CW 2000. A review of antimycobacterial natural products. Phytother Res 14: 302-322.

Novais TS, Costa JFO, David JPL, David JM, Queiroz LP, França F, Giulietti AM, Soares MBP, Santos RR 2003. Atividade antibacteriana em alguns extratos de vegetais do semi-árido brasileiro. Rev Bras Farmacogn 13: 5-8.

Oliveira FP, Lima EO, Siqueira Júnior JP, Souza EL, Santos BHC, Barreto HM 2006. Effectiveness of Lippia sidoides Cham. (Verbenaceae) essential oil in inhibiting the growth of Staphylococcus aureus strains isolated from clinical material. Rev Bras Farmacogn 16: 510516.

Oliveira RAG, Lima EO, Souza EL, Vieira WL, Freire KRL, Trajano VN, Lima IO, Silva-Filho RN 2007. Interference of Plectranthus amboinicus (Lour.) Spreng essential oil on the anti-Candida activity of some clinically used antifungals. Rev Bras Farmacogn 17: 186-190.

Pauli GF, Case RJ, Inui T, Wang Y, Cho S, Fischer NH, Franzblau SG 2005. New perspectives on natural products in TB drug research. Life Sci 78: 485-494.

Peng SC, Cheng CY, Sheu F, Su CH 2008. The antimicrobial activity of heyneanol A extracted from the root of Taiwanese wild grape. J Appl Microbiol 105: 485-491.

Pereira DF, Santos M, Pozzatti P, Alves SH, Campos MMA, Athayde ML 2007. Antimicrobial activity of a crude extract and fractions from Alternanthera brasiliana (L.) O. Kuntze leaves. Lat Am J Pharm 26: 893-896.

Ramos MC, Moraes MJ, Calisni AL, Roscani GN, Picolli EA 2000. A retrospective bacteriological study of mycobacterial infections in patients with acquired immune deficience syndrome (AIDS). Br J Infect Dis 4: 86-90.

Rangasamy O, Raoelison G, Rakotoniriana FE, Cheuk K, Urverg-Ratsimamanga S, Quetin-Leclercq J, GuribFakim A, Subratty AH 2007. Screening for anti-infective properties of several medicinal plants of the Mauritian flora. J Ethnopharmacol 109: 331-337.

Rauha J-P, Remes S, Heinonen M, Hopia A, Kähkönen M, Kujala T, Pihlaka K, Vuorela H, Vuorela P 2000. Antimicrobial effects of Finnish plant extracts containing flavonoids and other phenolic compounds. Int J Food Microbiol 56: 3-12.

Sankar MM, Gopinath K, Singla R, Singh S 2008. In-vitro antimycobacterial drug susceptibility testing of nontubercular mycobacteria by tetrazolium microplate assay. Annals of Clinical Microbiology and Antimicrobials 7: 15.

Schubert A, Pereira DF, Zanin FF, Alves SH, Beck RCR, Athayde ML 2007. Comparison of antioxidant activities and total polyphenolic and methylxanthine contents between the unripe fruit and leaves of Ilex paraguariensis A. St. Hil. Pharmazie 62: 876-880.

Soberón JR, Sgariglia MA, Quiroga EM, Vattuone MA 2007. Antibacterial activity of plant extracts from northwestern Argentina. J Appl Microbiol 102: 1450-1461.

Tosun F, Akyuz KC, Sener B, Vural M, P Palittapongarnpim 2004. Antimycobacterial screening of some Turkish plants. J Ethnopharmacol 95: 273-275.

Wasicky R, WasickyM,JoachimovitsR 1964.Erstuntersuchungen und Coronilha Scutia buxifolia Reissek. Planta Med 12: 13-25.

\section{*Correspondence}

Aline A. Boligon

Laboratório de Pesquisa Fitoquímica, Departamento de Farmácia Industrial, Universidade Federal de Santa Maria Prédio 26, sala 1411, 91105-900 Santa Maria-RS, Brazil alineboligon@mail.ufsm.br 